\title{
The Need for a Clear Legal and Contextual Framework to Distinguish Between the Crime of Genocide and the Crimes Against Humanity in Modern International Criminal Law.
}

\author{
SaadatuSalisuMatori ${ }^{1}$ and AbubakarBukar Kagu ${ }^{2}$ \\ School of Law, Politics and Sociology,University of Sussex.United Kingdom.
}

\begin{abstract}
Since the Nuremberg trials of the 1940s, there has been an expansion of the list of crimes recognized under international law. ${ }^{1}$ While crimes such as genocide and the crime against humanity were provided for under international Charters, most of their contextualisation came through various court interpretation of international customary law. ${ }^{2}$ What became obvious and somewhat complex to most scholars and commentators is the overlap between crimes against humanity and those considered as genocide. Espousing on the nature of this overlap, Fenrick states, "just as genocide has become the offense which represents what happened in Germany during 1944, so the crime against humanity and persecution has come to typify what happened in the territory of the former Yugoslavia., ${ }^{, 3}$ This paper intends to give a simplified overview of the existing contention both of definition and application and to also argue the importance of either a clear demarcation or a framework for harmonisation of the two crimes.
\end{abstract}

Keywords: Conflict, Court, Crime, Genocide, Humanity, International, Violation, Law.

\section{INTRODUCTION}

Unlike the crime of genocide, which is restrictedto some degree of specificity, crime against humanity seemed to cover an enormous array of acts and violations. Hence, as Wald argued, it has become "the growth stock of Tribunal jurisprudence." Except for the International Criminal Tribunal for the former Yugoslavia(ICTY), the crimeagainst humanity does not necessarily desire nexus with armed conflict because it "encompasses discriminatory acts against a much wider range of groups than genocide and much more kinds of acts than the five listed in the Genocide Convention and Charters." "In general, the definition of genocide had often been restricted to certain define groups and limits, while that of the crime against humanity haskept expanding. This expansion of what crime against humanity is, can be seen in the list contained in the Rome Statute of the International Criminal Court, which includes murder, extermination, enslavement, deportation or forcible transfer of population, imprisonment, torture and rape. It also includes sexual slavery, enforced prostitution, forced pregnancy, enforced sterilization, or any other form of sexual violence of comparable gravity; persecution against an identifiable group on political, racial, national, ethnic, cultural, religious or gender grounds enforced disappearance of persons. The list further covers the crime of apartheid as well as other inhumane acts of a similar character intentionally causing great suffering or serious bodily or mental injury. ${ }^{6} \mathrm{~A}$ close perusal of this list suggests how the terrain of international law regarding crimes against humanity is so vast that it has unavoidably become vulnerable not only to multiple interpretations but also creates the complex foundation for overlaps both with war crimes and genocide.

II. Distinguishing 'Crime Against Humanity'and the crime of 'Genocide'.

The earliest legal definition of 'Crime Against Humanity' was the one adopted under Article 6 of the Charter of the International Military Tribunal in 1945.The article gave the definition of this crime as that involving, "murder, extermination, enslavement, deportation, and other inhumane acts committed against any civilian population, before or during the war; or persecutions on political, racial, or religious grounds in execution of or in connection with any crime within the jurisdiction of the Tribunal, whether or not in violation

\footnotetext{
${ }^{1}$ Wald, P. M. (2007). Genocide and crimes against humanity.Wash. U. Global Studies Law Review, 6, 621-633. ${ }^{2}$ ibid

${ }^{3}$ Fenrick, W. J. (2001). The crime against humanity of persecution in the jurisprudence of the ICTY. Netherlands Yearbook of International Law, 32, 81-96.

${ }^{4}$ Wald, P. M. (2007). Genocide and crimes against humanity.Wash. U. Global Studies Law Review, 6, 621-633. ${ }^{5}$ Ibid.

${ }^{6}$ Article 7 of Rome Statute of the International Criminal Court 
of the domestic law of the country where perpetrated." Being that this definition came up a time when law was at its nascent stage of development, the emergence of these provisions, have, from their proclamation, attracted the attention of scholars and international lawyers. Principally, the promulgation wasreceived by many as a lofty conception that brings some fundamentally essential principles necessary for defining the role, objectives, and future of International law. ${ }^{8}$ This definitionembodies some fundamental elucidationon whatconstitutes crimes against humanity. ${ }^{9}$ The specificity of this explanation is to the extent that such a crime is deemed to have been perpetrated if:

(a) Before and during the war

(b) Against any civilian population

(c) Whether or not in violation of the domestic law of the country where perpetrated.

Evidently, the principles in this Charter presupposethat sanctions for such crimes are applicable both in times of war and in peace. However, the principles also raise some fundamental questions as the contents of this law technically imply that any civilian population is under the protection of international law even if the violation they suffer was meted by their own government.Moreover, the part which states that 'whether or not in violation of the domestic law of the country where perpetrated' further compound and expands the jurisdiction of international law making it appearas prevailing as municipal laws. ${ }^{10}$ One of the crucial problems with this overreach is that the Charter justifies the growing culture of interventionism by world powers in the affairs and crisis of smaller nations; a situation that in the last two decades prompted devastating wars and exacerbated chaos and unrest in many parts of the world, especially in the Middle East and Africa. Further complicating the role of International law and the international community is the assumption that this Charter allows such intervention in the affairs of other sovereign states not only during war but even in peace; in as much as there is sufficient ground to conclude that the population or a part of it has been violated. ${ }^{11}$ Paradoxically, this provision raises the question over the need to safeguard the principles of state sovereignty and non-intervention.

The crime of 'Genocide'on the other handwas first adoptedin 1948 following an earlier request in 1945 byLemkin who proposed a treaty against genocide to the United Nations. In the proposal, he recommended that genocidebe defined as "Whoever, while participating in a conspiracy to destroy a national, racial or religious group, undertakes an attack against life, liberty or property of members of such groups is guilty of the crime of genocide."12 The United Nations General Assembly ratified the Genocide Convention in 1948, and the law was entered into force in January $1951 .^{13}$ The text of Article II of the Genocide Convention was again included as a crime in Article 6 of the 1998 Rome Statute of the International Criminal Court. ${ }^{14}$

Inliteral term, 'Genocide' under international law means any act done todestroy a group's existence. This includes direct killing or inciting actions to cause death; causing serious bodily or mental harm or the deliberate deprivation of resources needed for the group's physical survival. It also includes any act offorcible relocation to a place where life becomes under threat.It also includes deliberate and malicious actions to prevent births. ${ }^{15}$

Article II of the Convention on the Prevention and Punishment of Genocide (CPPG) states that genocide means any of the following acts committed with intent to destroy, in whole or in part, a national, ethnical, racial or religious group, as such: ${ }^{16}$

(a) Killing members of the group.

(b) Causing serious bodily or mental harm to members of the group.

(c) Deliberately inflicting on the group conditions of life calculated to bring about its physical destruction in whole or in part.

(d) Imposing measures intended to prevent births within the group.

(e) Forcibly transferring children of the group to another group.

${ }^{7}$ Robinson, D. (1999). Defining" crimes against humanity" at the Rome Conference.American Journal of International Law, 43-57.

${ }^{8}$ Stanton, G. H. (2002). What is Genocide?.Genocide Watch.

${ }^{9}$ Cassese, A., Gaeta, P., Baig, L., Fan, M., \& Gosnell, C. (2013).Cassese's international criminal law. Oxford University Press.

${ }^{10}$ Schwelb, E. (1946). Crimes against humanity.British Year Book of International Law., 23, 178-266

${ }^{11}$ ibid

${ }^{12}$ Fein, H. G. (1993). A Sociological Perspective.Londres-Newbury Park, CA, SagePublications.

${ }^{13}$ Stanton, G. H. (2002). What is Genocide?. Genocide Watch; See also Quigley, J. (2013). The genocide convention: An international law analysis. Ashgate Publishing, Ltd..

${ }^{14}$ Article 8 of Rome Statute of the International Criminal Court

${ }^{15}$ Bisharat, G. E. (2001). Sanctions as genocide.Transnational Law and Contemporary Problems., 11, 379-394

${ }^{16}$ Ronayne, P. (2001).Never again?: the United States and the prevention and punishment of genocide since the Holocaust. Rowman and Littlefield. 
The punishable acts are stated under Article 111 of the Convention:

(a) Genocide.

(b) Conspiracy to commit genocide.

(c) Direct and public incitement to commit genocide.

(d) Attempt to commit genocide.

(e) Complicity in genocide.

By these ingredients as well as the notion of scholars such as Stanton, genocidehas two elements, i.e., intent and action. ${ }^{17}$ While intent can be proven from direct statements of the perpetrators or orders given to execute an action, it also can be inferred from "a systematic pattern of coordinated acts." 18 Whatever the motive is, once an act is committed with the aim of destroying a group, it is considered an act of genocide. It is also an act of genocide for an individual to partake in the act of killing or causing the death of another if he is aware his act is part of a larger scheme to exterminate a particular group. ${ }^{19}$ Similarly, as contained in Article II of the CPPG, the term "in whole or in part" connotes that, even if the target is a particular class or group within a larger group, it will qualify as an act of genocide, e.g., thekilling of members ofa political opposition group. ${ }^{20}$ These two crimes under review have for decades continued to overlap causing controversy on where the dividing line is between what constitutes genocide and what constitutes crimes against humanity. ${ }^{21}$ One of the prominent cases that caused a heated debate in recent history was the famous Serbian case of Milosevic, Mladic and Karadzic. ${ }^{22}$ The controversy among commentators was to answer the question of 'when' and 'how' the ethnic cleansing campaign of the trio became a case of genocide. Karadzic and Mladic have both been indicted for genocide, and another General Krstic was found guilty of aiding and abetting genocide. ${ }^{23}$ While some see the mass murder of ethnic Bosnian Muslim men in Srebrenica as an act of genocide, others were of the view that genocide was not committed. Instead, it is a case of ethnic cleansing. ${ }^{24}$ Yet, the contents of Article II of the CPPGare very clear that any deliberate infliction on a group any harm calculated to destroy such group in whole or in part is tantamount to genocide. ${ }^{25}$ Hence, the targeting and near annihilation of a particular group of people in Srebrenica can successfully qualify as a crime of genocide.

\section{SIMILARITIES AND DIFFERENCES}

Because the definition of genocide under the Genocide Convention of 1948 has remained textually static, there had been an upsurge in the debate over the overlaps as well as the dissimilarities between thecrime of genocide and the crime against humanity as defined and enforced by international and hybrid courts. ${ }^{26}$ These interpretations, generated from various interpretations over the past two decades have brought to the core some contextual and substantive problems, especially in clearly identifying, defining and categorising the extent and limits of what could be termed as genocide and what is to be considered as acrime against humanity. ${ }^{27}$ Although the drafts men of the Rome Statute 3 and its 'Elements of Crime' have produced a document in 2000 which incorporates the best of the ad hoc courts' interpretations of these two crimes, the attempt was to a larger extent to set out principles of international customary law. ${ }^{28}$ The challenge of adapting a distinction between the two crimes has continued to become a polemical topic in international law, prompting scholars such as Walds to state that "we must always keep in mind that the origin of international humanitarian law crimes isdifferent from national crimes." 29 In international crimes he argues, legitimacy is derived mainly from international customary

\footnotetext{
${ }^{17}$ Stanton, G. H. (2002). What is Genocide?.Genocide Watch.

${ }^{18}$ ibid

${ }^{19}$ Wald, P. M. (2007). Genocide and crimes against humanity. Wash. U. Global Stud. L. Rev., 6, 621.

${ }^{20}$ ibid

${ }^{21}$ Theodorakis, N., \& Farrington, D. P. (2013). Emerging Challenges for Criminology: Drawing the Margins of Crimes against Humanity. International Journal of Criminology and Sociological Theory, 6(2).

${ }^{22}$ Wald, P. M. (2007). Genocide and crimes against humanity.Wash. U. Global Studies Law Review, 6, $621-633$.

${ }^{23}$ Dawson, G., and Boynton, R. (2008).Reconciling Complicity in Genocide and Aiding and Abetting Genocide in the Jurisprudence of the United Nations Ad Hoc Tribunals.Harvard Human Rights Journal, 21, 241-286

${ }^{24}$ Schabas, W. A. (2005). Genocide, Crimes Against Humanity, and Darfur: The Commission of Inquiry's

Findings on Genocide. Cardozo Law Review, 27, 1703-1745

${ }^{25}$ Tams, C., Berster, L., \&Schiffbauer, B. (Eds.). (2014). Convention on the Prevention and Punishment of the Crime of Genocide: A Commentary. Bloomsbury Publishing.

${ }^{26}$ Donoho, D. L. (2006). Human Rights Enforcement in the 21st Century.bepress Legal Series, 1282.

${ }^{27}$ Schabas, W. A. (2016). Atrocity crimes (genocide, crimes against humanity and war crimes) 10.The Cambridge Companion to International Criminal Law, 199.

${ }^{28}$ Paust, J. J. (2009). International Criminal Court Does Not Have Complete Jurisdiction over Customary Crimes against Humanity and War Crimes, The. J. Marshall Law Review, 43, 681-714

${ }^{29}$ Wald, P. M. (2007). Genocide and crimes against humanity.Wash. U. Global Studies Law Review, 6, 621-633.

DOI: $10.9790 / 0837-2202017378 \quad$ www.iosrjournals.org $75 \mid$ Page
}


law and sometimes treaties. ${ }^{30}$ The paradox here is, not all treatiesqualify as expressions of customary law,especially if they have not been adopted or adhered to by a majority of 'so called' civilized nations. ${ }^{31}$ Likewise, not all international customary law is incorporated in treaties. ${ }^{32}$ In reality, international law, unlike municipal laws, does not lend themselves so easily to periodic re-examination and modificationsimply because of the need to establish an integrated body of law. ${ }^{33}$ Hence, it has become more of a'discourse of interpretation' to differentiate the elements of these two crimes than it is a matter of reviewing the Charters that define them. Untilthe definition of genocide under the Genocide Convention (which is now recognized as customary law and repeatedly contained in Charters of the international courts)is reviewed, alongsidethe International Convention on Crimes Against Humanity, both definitions and contents will continue in the same complexoverlapping fashion. ${ }^{34}$ Essentially, without reviewing these laws, the controversies are bound to continue. Other scholars maintained that there is lack of political to review the laws mainly due to the concern that if proposed amendments to the existing definition of genocide is entertained, then, "either the core itself might be endangered, or it might result in a runaway expansion so as to make it indistinguishable from its country cousin, crimes against humanity. ${ }^{.35}$ Despite the argument of overlap, a careful perusal into the textual provisions that describe the two crimesappearto reveal certain differences. ${ }^{36}$ For example, crime against humanity requires that the act perpetrated be a deliberate targeting of a civilian population in a systematic or widespread manner. Genocide, on the other hand, refers to a targeted act against the specific groups listed, i.e., ethnic, racial, religious or national groups with the specific intent of annihilating the group or a selected part of it.It also matters less if only a few people were targeted, it would still constitute genocide.An addition to the provisionsofthe statute further states thatthe conduct is one that took place in the context of a manifest pattern of similar conduct directed against that group or was, in fact,a conduct that could in itself result in such destruction. ${ }^{37}$ Although the crime of genocide within the context of this definition may seem restrictive; it is definitive. It is, however, noteworthy to stress that this definition has attracted criticism on the ground that its limitation has failed to include other vulnerable groups such as women and children. Yet, other scholars were of the opinion thatit is important tolimit the scope of this definition in order ensure that the genocide remains to be considered as the worst of all crimes, and also toguarantee that the law did not lose its "deterrent currency through too expansive application to every kind of massacre. ${ }^{38}$ On what constitutes crime against humanity, scholars have, over the years, made concerted attempts in giving an analogical description. Arendt, for example, described acts like the Holocaust as "a crime against humanity perpetrated upon the body of the Jewish people. ${ }^{139}$ But over the last three decades, this pattern of analogy has expanded the scope of what a crime against humanity is that it now encompasses an array of different kinds of violations, from sex slavery to forced labour. The crime of genocide on the other hand has maintained its restricted and 1;imted scope to the four defined elements,i.e., targeting with specificity an ethnic, racial, religious or national groups. ${ }^{40}$ This precision with which the Charter on genocide was drafted has remained intact both in form and substance but for some minor modifications in the Rome Statute, mainly contained in the provision that describes Elements of Crime. ${ }^{41}$

\section{The significance of a new and clear legal framework in contemporary international law}

It is evident that the link and overlap between the crime of genocide and the crime against humanity would continue to present parallel debates on when an act spills over from one form to the other. This complexity does not appear to be resolved by statutes or by interpretations. Instead, it becomes further compounded as the definition and character of the elements contained in the Charters become distorted through various interpretations. Tracing the root of this complexity, inconsistency, and overlap, one is bound to relate them back to historical challenges inherited since the promulgation of the conventions. For instance, what would today

\footnotetext{
${ }^{30} i$ bid

${ }^{31}$ Goldsmith, J. L., \& Posner, E. A. (2005). The limits of international law (Vol. 199). Oxford: Oxford

University Press.

${ }^{32}$ Ibid.

${ }^{33}$ Alter, K. J. (2014). The new terrain of international law: Courts, politics, rights. Princeton University Press.

${ }^{34}$ Goldsmith, J. L., \& Posner, E. A. (2005).The limits of international law.Oxford: Oxford University Press.

${ }^{35} \mathrm{Ibid}$.

${ }^{36}$ Geras, N. (2015). Crimes against humanity: Birth of a concept. Oxford University Press.

${ }^{37}$ Triffterer, O. (2001). Genocide, its particular intent to destroy in whole or in part the group as such.Leiden Journal of International Law, 14(2), 399-408.

${ }^{38}$ Wald, P. M. (2007). Genocide and crimes against humanity. Wash. U. Global Studies Law Review, 6, 621-633.

${ }^{39}$ Barry Gewen, TheEveiyinan of Genocide, N.Y. TIMES, May 14, 2006.

${ }^{40}$ Schabas, W. A. (1999). Groups protected by the Genocide Convention: Conflicting interpretations from the

International Criminal Tribunals for Rwanda. ILSA J. Int'l \& Comp. L., 6, 375.

${ }^{41}$ Balint, J. (2011).Genocide, State Crime, and the Law.Routledge.

DOI: $10.9790 / 0837-2202017378 \quad$ www.iosrjournals.org $\quad 76 \mid$ Page
}


constitute genocidewas treated as a crime against humanity during the Nuremberg trial. ${ }^{42}$ What is becoming increasingly topical and important is the need to reform the framework of international law, particularly on these two crimes in order to deal witgh the way technicalities of interpretation are eroding what should otherwise be an undiluted conversation on ways to deal with a crime that has been committed or a violation that has occurred. While the list of what constitute crimes against humanity covers most of the acts that are deemedmost relevant causativethat explains crimes against a people or a community, ${ }^{43}$ the duplicity and division between genocide and the crime against humanity only creates a room that diverts attention from the most crucial elements of a violation and resorting instead to some abstract and technical explanation of terms. There are, however, clear instances where the two were separated. One example is the Khmer Rouge regime's act of mass atrocity against millions of city dwellers and upper social class. ${ }^{44}$ There is widespread agreement among commentators that such groups do not qualify for genocide treatment as "racial, religious, national or ethnical." ${ }^{\text {"Similarly, the alleged }}$ Darfur atrocities in the Sudan-purposeful killings, rapes and relegation of villagers to a way of life almost certain to destroy them have beenlabeledby an expert in the UN Commission of Inquiry as likely crimes against humanity rather than genocide. ${ }^{46}$ There is, however, another point that this paper intends to put cross, which is for the international law to either focus on developing a homogenous framework for either crimes or work towards clearly splitting them into two distinct forms of violationin order to solve the decades of sustained overlap and confusion on the dividing line between the two. ${ }^{47}$ The inconsistency and confusion of the existing definitions have prompted leading contemporary scholars such as Schabas to suggest that there "have been no convictions for genocide where a conviction for crimes against humanity could also not have been sustained." ${ }^{48}$ Murray also argues that "the international criminal tribunals have operated produced volumes of case law, which has strengthened and developed the concept of crimes against humanity to the extent that prosecuting individuals for genocide must at least be questioned." ${ }^{49}$ Although the crime of genocide can be merged with the crime against humanity under a single provision of a consolidated statute, to do that demands a thorough examination of the elements of both crimes and coming up with a text that would be able to cover most of the violations that international law intends to curtail.Given all the polemics surrounding the definition and contextualisation of both crimes, the need arises for a review of how international law deals with both the definition and substance of these crimes. As many scholars argue, there is the imminent need for a review of the Charters by revisiting some of the fundamental aspects of theirprovisions. For example, a closer understanding of Article 7 of the Rome Statute suggests that crime against humanity is a conduct that involves the multiplecommissions of acts against any civilian population pursuant to, or in furtherance of a state or organized policy to commit such act of violation. ${ }^{50}$ This clearly means that one person cannot by himself commit crime against humanity; it has to be systemic and through a wider campaign. The act also has to be a part of a wider framework designed and executed against a civilian population. The phrase "systematic or widespread" contained in the provision argued WALD, presents its own kind of challenge and obstacle. ${ }^{51} \mathrm{He}$ gave example with the Rwandan civil war, pointing out that "the existence of widespread and systematic attacks on civilians as well as an internal armed conflict were held to be notorious facts not subject to reasonable debate" by theInternational Criminal Tribunal for Rwanda(ICTR), whereas as in the Balkans or Sierra Leone the position was relatively dissimilar. ${ }^{52}$ There is also the danger that the emphasis given to technical explanations or definitions is affecting the consensus with which scholars and stakeholders are supposed to build a coherent approach to what is, for all intent and purpose, a humnitarian and civilised way to ensure that people subjected to deliberate and calculated harm whether as a result of their social affiliations or because of their natural or

\footnotetext{
${ }^{42}$ Schabas, W. (2000). Genocide in international law: the crimes of crimes. Cambridge University Press. ${ }^{43}$ ibid

${ }^{44}$ Schabas, W. A. (2000). Problems of International Codification-Were the Atrocities in Cambodia and Kosovo Genocide. New Eng. L. Rev., 35, 287.

${ }^{45}$ Clark, R. S. (2001). The Mental Element in International Criminal Law: The Rome Statute of the International Criminal Court and the Elements of Offences. In Criminal Law Forum, 12, 3,291-334.

${ }^{46}$ Murray, A. R. (2011). Does International Criminal Law Still Require a Crime of Crimes: A Comparative Review of Genocide and Crimes against Humanity.Goettingen Journal of International Law, 3, 589-615.

${ }^{47}$ Chesterman, S. (2000).An Altogether Different Order: Defining the Elements of Crimes Against Humanity.

Duke Journal of Comparative and International Law, 10, 2, 342-387

${ }^{48}$ Schabas, W. A. (2006). The UN international criminal tribunals: the former Yugoslavia, Rwanda and Sierra Leone. Cambridge University Press.

49 ibid

${ }^{50}$ Fenrick, W. J. (1998). Should crimes against humanity replace war crimes. Columbia Journal of Transnational Law., 37, 767-802

${ }^{51}$ Wald, P. M. (2007). Genocide and crimes against humanity. Wash. U. Global Studies Law Review, 6, 621-633. ${ }^{52}$ ibid 
biological uniqueness get retribution and justice. ${ }^{53}$ By allowing less relevant overtures to erode substantive reasoning, the fundamental objective of international justice risk been subjected to the kind of irrational and illogicalovertures that affect the fabric of justice. Evidence from the Rwandan civil war has, for instance, brought to the forefront this kind of problem. Giving credence and emphasis to whether the Hutu and Tutsi are ethnically different is an irrational distraction from the real issue, which is the gravity of the offence committed and the plight of the victims. ${ }^{54}$ This gravitation from the substantive questions to the trivial has led to frustration among human rights activists and scholars prompting the question on whether the Tribunal is interested in thesubstantive exploration of the issues of mass atrocity or more concerned with the overtures on where to situate the crimes committed. ${ }^{55}$

\section{CONCLUSION}

Both the crime of genocide and the crime against humanity are still part of the integral provisions of the Rome Statute, and the main overreaching precedents laid down regarding theInternational Criminal Court(ICC), are the ones drawn from the ICTY and the ICTR. Themajor complexity for most observers is about the way the ICC will approach cases of genocide since it would inevitably draw on the jurisprudence of the ICTY and the ICTR. ${ }^{56}$ Principally, crime against humanity provides a far more overarching category of crimesthanthe restrictive definition of genocide. Also important is the fact that by elevating or expanding the scope, the laws risk becoming overloaded with different elements that the gravity of what the law originally intends to combat may be eroded. Admittedly, what municipal laws can afford regardingreviews may not be suitable for international law regime. This isbecause; the homogeneity that international law intends to create regardinginternational doctrines, principles, and guidelines on justice and penology is so fragile that it requires cautious and steady approach.Moreover, seeking and securing unanimity of nations on a particular law, its elements, ingredients, and reach is a task that touches on international relations as well as the inherent geopolitical and strategic interest of many players around the world. Yet, it is also not in the interest of international law and the global; community to ignore the fact that the confusion and polemics surrounding the definition and elements of the two crimes under review should not be revisited because of some of the reasons mentioned earlier. International law as a system is still in the stage of it development and therefore open to a lot of reforms capable of strengthening its provisions not to neglect aspects capable of weakening the system.

Now that these laws appear to look like a multiplication of the same statute, a move can be made to consolidate them into one or make their differences as clearer as possible to avoid the kind of distraction and controversy that has continued for decades. This is a significant proposition if international law is to detach itself from the unnecessary diverse interpretations, analogical conclusions, and confusing overlaps.Resolving the decades of inconsistency and arguments over the extent of crimes against humanity and the limits of genocide is now as important as the definition of the crime itself.This is because, time and again, this overlap has created the tendency to overshadowlegitimate question about the crimes that have already been committed; and of the victims that are awaiting justice. In the quest for this reform, there is another factor that international law has to deal with, which according to Wald is that, "genocide has taken on a life of its own in the popular mind; victims of almost all massacres feel cheated when a court or commission finds that their perpetrators have only committed a crime against humanity not a genocide". ${ }^{57}$ Because of these kinds of popular sentiments among victims, and the fact that events like the previous cases of genocide may surface in the future, international law has to deal with this complexity as well. One way to do that, at least if the two crimes cannot be consolidated into one, is to regard all acts of mass violations as crimes against humanity, whether it is against a group not affiliated by religion, race, ethnicity or nationality, or whether it is against a population defined by such social, political, geographic or biological characteristics.

\footnotetext{
${ }^{53}$ For discourse on interpretation and compliance, See: Falk, R. A. (2015). Status of Law in International Society.Princeton University Press.

${ }^{54}$ Reyntjens, F. (2004). Rwanda, ten years on: From genocide to dictatorship. African affairs, 103(411), 177-210; Uvin, P. (1999). Ethnicity and power in Burundi and Rwanda: Different paths to mass violence. Comparative politics, 253-271.

${ }^{55}$ Murray, A. R. (2011). Does International Criminal Law Still Require a Crime of Crimes: A Comparative Review of Genocide and Crimes against Humanity.Goettingen Journal of International Law, 3, 589-615.

${ }^{56}$ Murray, A. R. (2011). Does International Criminal Law Still Require a Crime of Crimes: A Comparative Review of Genocide and Crimes against Humanity.Goettingen Journal of International Law, 3, 589-615.

${ }^{57}$ Wald, P. M. (2007). Genocide and crimes against humanity. Wash. U. Global Studies Law Review, 6, 621-633. 